\title{
The Study of Accounting Conservatism after the Promulgation of New Accounting Standards for Enterprises - Based on the Evidence in China's Capital Market
}

\author{
Meng Wang ${ }^{1}$ \\ ${ }^{1}$ School of Economics and Management, Zhejiang Industry Polytechnic College, Shaoxing, China \\ Correspondence: Meng Wang, School of Economics and Management, Zhejiang Industry Polytechnic College, \\ Shaoxing, China. Tel: 86-159-2580-5162. E-mail:wm2712@yahoo.com.cn
}

Received: January 4, 2013

Accepted: January 31, $2013 \quad$ Online Published: February 5, 2013

doi:10.5539/ibr.v6n3p183

URL: http://dx.doi.org/10.5539/ibr.v6n3p183

\begin{abstract}
The accounting conservatism is the important topic of academic research in China and other countries, the Ministry of Finance promulgated accounting standards for enterprises which looks upon accounting conservatism as one of the principles for the first time in November, 1992 in China. And the Ministry of Finance issued a new Accounting Standards for Enterprises which regards the accounting conservatism as the quality requirements of accounting information in February, 2006. Thus the importance of accounting conservatism can be vividly seen. This paper uses the companies as the research samples after the implementation the new accounting standards for enterprises promulgated, that is to say, I choose the data from 2008 to 2011 for 4 years as research samples. Using Ball and Shivakumar's (2005) accrued - cash flow model, but the model was modified, specific practice is to divide accruals into discretionary accrual items and non-discretionary accrual items, the results of multiple regression show that China's accounting earnings is conservative, but accounting conservatism stems from non-manipulative accruals.
\end{abstract}

Keywords: accounting conservatism, accruals, discretionary accrual items, non-discretionary accrual items

\section{Introduction}

Early in the middle ages, accounting conservatism as a measurement principle was widely applied in the commercial activities. In early fourteenth century, Henley in his book housekeeping suggested that the personnel in the audit of the manor should maintain loyalty and caution. Bliss (1924) is the man who gives the definition of conservatism for the earliest, he states conservatism as "to foresee all possible losses, but don't expect any uncertain income". FASB (1980) in the Announcement of Financial Concept No. 2 gives the characterization of conservatism which is "the reflection of uncertainty carefully". IASB (2008) states the conservatism as "under uncertain conditions, the prudence of a certain degree was included when the use of judgement required obtains the necessary estimation, for example the assets or incomes cannot be overestimated, liabilities or expenses can not be underestimated". The new accounting standards for enterprises issued in February, 2006 in China defines the conservatism as follows: the conservatism requires that confirming and measuring and reporting transactions or matters should be prudent in corporations, assets or income should not be overstated, liabilities or costs should not be underestimated.

In the early stage of the People's Republic of China, the economic system of China is basically planned-economy system, until 1978, after the Third Plenary Session of the Eleventh Central Committee, China implemented fundamental state policy of reform and opening-up, gradually reformed the original economic system, especially in the Fourteenth National Congress of the Communist Party of China in 1992, building the marketable economic system of socialist is the target of the reform of economic system. Therefore, the accounting serving for the economy will also undertake a series of reform in order to adapt to the changes of China's economic environment. The Ministry of Finance issued the new accounting standards for enterprises ( implemented in July 1, 1993) in November 30, 1992, it can be said that the new standards was promulgated in order to adapt to the development of the Chinese market economy, the guidelines regards accounting conservatism as one of the basic principles of accounting for the first time, thus it can be seen that the accounting conservatism is very important. China formally joined WTO in November 10, 2001 and has become one member 
of the World Trade Organization. From then on, the relationship between China's economic development and the development of the global economy is more closely, what's more the world itself is the era of global economic integration. So the Ministry of Finance issued a new enterprise accounting standards in order to meet the needs of development of the global economy and to make China's accounting standards conform with international standards and at the same time to adapt to the needs of the reform of the market economic system. All listed corporations were claimed to begin to implement the new accounting standards in January 1, 2007, and the accounting conservatism is also mentioned as one of qualitative characteristics of accounting information in this new standards. Since the accounting conservatism (prudence) is so important, furthermore the accounting standards for business enterprises of China also looks upon conservatism as accounting principles, I can not help asking the Minestry of Finance requires corparations to follow the conservatism, but the accounting in enterprises does really reflect the accounting conservatism? This paper wants to verify if the conservatism of accounting earnings does exist in listed corporations of China through the method of empirical research? And to explore if the accounting conservatism exists, further to ask what the conservatism of accounting earnings stems from in the capital market of China?

\section{A Review of the Literature}

\subsection{Foreign Literature Review}

Watts (1993) is the earliest man who conducts systematic research on accounting conservatism, he mainly studied the reasons of the formation of the conservatism, and thought that accounting conservatism primarily arises from the debt contract and subject to the regulatory and legal effect, but his primary method is normative research method, and didn't find the method of empirical research metering accounting conservatism, but he thought that accounting conservatism can be inspected through empirical research. The legal systems of the United States have changed since 1966, which supplied an opportunity that tested whether legal proceeding is a factor of conservatism or not (Kothari, 1988). Ahmed etc. (2002) found that the conflict between shareholders and creditors is stronger, and the degree of accounting conservatism is higher. What's more, the degree of conservatism is higher, the debt cost of corporations is lower, which proves that the debt contract is one of the reasons of the conservatism. Basu (1997) is the earliest man who used the method of empirical research to test the conservatism of accounting earnings, and built the surplus-stock return model ,namely the rate of stock return represents the good news or the bad news, if the accounting earnings is able to reflect the bad news more timely, accounting earnings is conservative. Gioly and Hayn (2000) used the book-to-market ratio, the characteristics of earnings distribution and the accumulative amount of non-operational accruals and the changes of symbol to measure accounting conservatism, and thought that the systematic difference between the operating cash flow and accounting earnings exists, the difference is caused by the non-operational accruals. Holthausen and Watts (2001) used Basu's surplus- stock return model to test the conservatism of accounting earnings of listed corporations from 1927 to 1993 in the capital market of the United States ,it was found that the accounting earnings in the United States appeared before 1966, and verified that accounting conservatism has existed before the emergence of accounting standards. Lara etc. (2005) used France, Germany and Britain's listed corporations as the samples, and he separating the normal accruals and discretionary accruals ,found the cause of accounting conservatism of British's listed corporations by using Jones' model, namely managements transfer useful information to investors through discretionary accrual. Ball and Shivakumar (2005) established the accrued-cash flow relation model to examine the accounting conservatism of earnings, and they thought that accruals could confirm the economic profit and loss timely, and tested the existence of accounting conservatism through the model and drew a conclusion that the conservatism is caused by accruals. Afterwards, Basu's (1997) earnings -stock return model and Ball and Shivakumar's (2005) accrued-cash flow model were mainly used overseas to study the conservatism of accounting earnings extensively and thoroughly.

\subsection{A Review of Literature in China}

$\mathrm{Li}$ and $\mathrm{Lu}$ (2003) used the data of A-shares of China's listed corporations from 1995 to 2000, the conservatism of accounting earnings has at least been validated with Basu's earnings-stock return model in the period. Zhao (2004) used Basu's earnings-stock return model, and the listed corporations of A-shares of Stock Market in Shanghai and Shenzhen were applied as research samples from 1994 to 2004, the results found that the conservatism of accounting earnings in China has been more greatly improved than previous years after 1998, and the conclusion was drawn that the conservatism of China's accounting earnings is improved due to cash flow instead of accruals. Xia and Zhu (2009) used Ball and Shivakumar's (2005) accrued-cash flow model to examine the data of listed corporations of A-shares from 1999 to 2006 in China, the results showed that China's accounting earnings is conservative, but it is caused by the non-operational accruals. Qiu and Qu (2009) used Ball and Shivakumar's (2005) accrued-cash flow model to examine empirically the data of samples of listed 
corporations of A-shares of stock market in China's Shanghai and Shenzhen from 2001 to 2005, and the results showed that the conservatism of China's accounting earnings exists, but the conservatism is caused by the discretionary accrual items. Hong and Xu (2009) selected the data of listed corporations of A-shares in 2007 in Shanghai and Shenzhen, and used Ball and Shivakumar's (2005) accrued-cash flow model to confirm the existence of accounting conservatism of listed corporations, they didn't divide accruals into the discretionary accrual items and non-discretionary accrual, and thought that conservatism stemmed from accruals. I have discovered that Basu's (1997) earnings-stock return model and Ball and Shivakumar's (2005) accrued-cash flow model are mainly being used to study empirically the conservatism of accounting earnings after I read the documents in China.

\section{Research Design}

The purpose of this paper is to discuss if the conservatism of China's accounting earnings in listed corporations does exist after the new accounting standards for business enterprises was implemented in January 1, 2007? And to explore the root of its formation? The design on empirical research is elaborated as follows:

\subsection{Model Established and Variables Defined}

Before and after the financial crisis in 2008, China's capital market is still immature, China's stock market fluctuated gravely, such as Composite Index in Shanghai Stock Exchange from the highest point 6124 in 2007 to the lowest point 1664 in 2008, then rebounded to its peak 3478 in 2009, the great fluctuation in stock market will make surplus - stock return model represented "the good news" or "bad news" with stock return rate deviate, so this paper adopts Ball and Shivakumar's (2005) accrued-cash flow model to measure the accounting conservatism. Healy (1985) has divided accruals into discretionary accrual items and non-discretionary accruals according to if the accruals is influenced by the subjective judgment of business management, so based on this, this article has modified Ball and Shivakumar's (2005) accrued-cash flow model, namely dividing accruals into discretionary accrual items and non-discretionary accruals. And discretionary accruals is widely used to measure earnings management in academic circle, so the measurement model of earnings management will be first chosen. Xia (2003) thinks that earnings management can be the most effectively revealled by cross-section Jones' the model which is handled by branch of industry estimation and the total accruals before the items used below the line (Note 1) as dependent variables to estimate parameters. Through the method of the empirical test, Liu (2011) verified that earnings management can be effectively measured by the modified Jones' model handled by year and industry in Chinese capital market. Through the empirical study, Subramanyam (1996) showed that cross-section Jones' model and modified cross-section Jones' model can more effectively reveal the behaviors of earnings management than time series model. Therefore, this paper uses the Jones' model handled by year and industry to measure earnings management. Combining Xia's (2003) with Liu's (2011) conclusions of empirical research, first the basic Jones' model (Model 1) is established to obtain the characteristic parameters in industries, and then the characteristic parameters in industries are put into modified Jones' model (Model 2), and non-discretionary accrual items are achieved, then discretionary accrual items can be calculated according to accruals equals discretionary accrual items plus non-discretionary accruals. In addition, Francis, Maydew and Sparks (1999) considered that the earnings management is to increase profits or reduce profits in unclear cases, discretionary accruals are taken the absolute value in order to measure more effectively the level of earnings management, so in this paper discretionary accruals have been taken absolute value.

$$
\begin{gathered}
\quad \frac{G T A_{i, t}}{A_{i, t-1}}=\alpha_{1} \frac{1}{A_{i, t-1}}+\alpha_{2} \frac{\Delta R E V_{i, t}}{A_{i, t-1}}+\alpha_{3} \frac{P P E_{i, t}}{A_{i, t-1}}+\varepsilon_{i, t} \\
\frac{N D A_{i, t}}{A_{i, t-1}}=\alpha_{1} \frac{1}{A_{i, t-1}}+\alpha_{2} \frac{\Delta R E V_{i, t}-\Delta R E C_{i, t}}{A_{i, t-1}}+\alpha_{3} \frac{P P E_{i, t}}{A_{i, t-1}}
\end{gathered}
$$

(Model 1)

In Model 1 and model 2, $\mathrm{GTA}_{\mathrm{i}, \mathrm{t}}$ presents the total accruals of company $\mathrm{i}$ in $\mathrm{t}$ year, its value is equal to operating profit plus net cash flow of operating activities; $A_{i, t-1}$ reprents the total assets of company i in t-1 year; $\Delta R V_{i, t}$ reprents the business income variation of corporation $\mathrm{i}$ in $\mathrm{t}$ year; $\triangle \mathrm{REC}_{\mathrm{i}, \mathrm{t}}$ reprents the net variable quantity of accounts receivable of company $i$ in t year; $\mathrm{PPE}_{\mathrm{i}, \mathrm{t}}$ reprents the value of fixed assets (Notes 2) of company $\mathrm{i}$ in $\mathrm{t}$ year. $\mathrm{NDA}_{\mathrm{i}, \mathrm{t}}$ represents non-discretionary accrual items of company $\mathrm{i}$ in $\mathrm{t}$ year; $\alpha_{1}, \alpha_{2}, \alpha_{3}$ respectively presents characteristic parameters about industry; $\varepsilon_{i, t}$ reprents residuals of company $i$ in $t$ year.

This paper uses Ball and Shivakumar's (2005) accrued-cash flow model to measure the conservatism of accounting earnings, but this model has been modified, namely the accruals are divided into discretionary accrual items and non-discretionary accrual items in this paper. On this paper my aim is to examine if accounting conservatism does exist in China? Under the existence of the accounting conservatism, its cause of formation is 
accruals or discretionary accrual items or non-discretionary accrual items? Based on this, the three models as follows are been established, Model 3 is the original model of accrued-cash flow, Model 4 and Model 5 are the modified model of accrued-cash flow model:

$$
\begin{gathered}
\operatorname{Acc}_{i, t}=\alpha_{0}+\alpha_{1} C_{F O_{i, t}}+\alpha_{2} D_{C F O_{i, t}}+\alpha_{3} C F O_{i, t} \times D C F O_{i, t}+\varepsilon_{i, t} \\
\text { OperAcc }_{i, t}=\alpha_{0}+\alpha_{1} C F O_{i, t}+\alpha_{2} D C F O_{i, t}+\alpha_{3} C F O_{i, t} \times D C F O_{i, t}+\varepsilon_{i, t} \\
\text { NoperAcc }_{i, t}=\alpha_{0}+\alpha_{1} C F O_{i, t}+\alpha_{2} D C F O_{i, t}+\alpha_{3} C F O_{i, t} \times D C F O_{i, t}+\varepsilon_{i, t}
\end{gathered}
$$

In Model 3, Model 4 and Model 5, $\mathrm{ACC}_{\mathrm{i}, \mathrm{t}}$ represents accruals of company $\mathrm{i}$ in $\mathrm{t}$ year divide the total assets at the beginning of the period, its value is equal to the operating profit (Notes 3) in t period minus net cash flow of operational activities in $t$ period. $\mathrm{CFO}_{\mathrm{i}, \mathrm{t}}$ represents net cash flow of operational activities of company $\mathrm{i}$ in $\mathrm{t}$ period divide the initial total assets. $\mathrm{DCF}_{\mathrm{i}, \mathrm{t}}$ is virtual variables, when $\mathrm{CFO}_{\mathrm{i}, \mathrm{t}}$ is less than $0, \mathrm{DCFO}_{\mathrm{i}, \mathrm{t}}$ is equal to 1 , otherwise its value is equal to $0 . \mathrm{CFO}_{\mathrm{i}, \mathrm{t}} \times \mathrm{DCF}_{\mathrm{i}, \mathrm{t}}$ is interactive projects and indicates the relationship between accrual and negative cash flow. $\varepsilon_{i, t}$ reprents residuals of company $\mathrm{i}$ in $\mathrm{t}$ period. OperAcc $\mathrm{i}_{\mathrm{i}, \mathrm{t}}$ represents discretionary accruals, NoperAcc $c_{i, t}$ represents non-discretionary accrual items. Ball and Shivakumar (2005) thought that accruals in the model (Model 3) mainly have two functions: one is to reduce the "noise" of cash flow; the other is the asymmetric confirmation of unrealized gains and losses. Based on the first role, the relationship between accruals and cash flow is negative correlation, $\alpha_{1}$ is expectedly negative; The second role showed that loss is more timely responsed than gains, or bad news (negative cash flow) is timely reflected in accruals, if the coefficient of $\alpha_{3}$ is significantly positive, the positive correlation between accruals and negative cash flow will be stronger, the model can not only test the "noise" of accruals reducing operating cash flow, can but also verify the existence of accounting conservatism.

\subsection{Samples Selected}

In January 1, 2007 , China's listed corporations started the implementation of the new accounting standards for enterprises, therefore I select the corporations after the new guidelines implemented as the research samples, the asset indicators in the last period in the selected model is needed and make the data comparable, so the data of listed corporations of A-shares in Shanghai and Shenzhen are selected as research samples from 2008 to 2011. In the process of the samples selected, I follow the following principles: (1) because of the particularity of financial and insurance enterprises, these corporations are eliminated; (2) because accounting earnings about initial public offerings' company in the current year is different from other years, the IPO companies are rejected; (3) ST companies are eliminatied in order to make the data more comparable; (4) the elimination of abnormal value of ACC and CFO in the samples, the specific practice is to remove one percent of the largest and the smallest samples; (5) the companies which are insufficient in data are removed; (6) In using Jones' model, the industry is classified, classification criteria is based on listed corporations industry classification direction issued by China Securities Regulatory Commission in 2001, listed corporations in the guidelines are divided into 13 major categories, because manufacturing industries in class $\mathrm{C}$ are numerous, based on this, manufacturing industries in this paper are further classified in accordance with two level code, taking into account the small number of samples about C2 (less than 10 each year from 2008 to 2011), thus combining it into other manufacturing industries C9; communication and cultural industries in class $\mathrm{L}$ are small sample size (less than 10 each year), so the category is directly removed. Together, combining samples' selection principle (1) and (6), financial and insurance industries and communication and culture industries are eliminated, merging $\mathrm{C} 2$ into $\mathrm{C} 9$, the samples are divided into 19 sectors, specific distribution about samples in each year is in Table 1.

Table 1. The industry classification

\begin{tabular}{lllllllllllllllllllllll}
\hline Industry & $\mathrm{A}$ & $\mathrm{B}$ & $\mathrm{C} 0$ & $\mathrm{C} 1$ & $\mathrm{C} 3$ & $\mathrm{C} 4$ & $\mathrm{C} 5$ & $\mathrm{C} 6$ & $\mathrm{C} 7$ & $\mathrm{C} 8$ & $\mathrm{C} 9$ & $\mathrm{D}$ & $\mathrm{E}$ & $\mathrm{F}$ & $\mathrm{G}$ & $\mathrm{H}$ & $\mathrm{J}$ & $\mathrm{K}$ & $\mathrm{M}$ & $\mathrm{Total}$ \\
\hline 2008 & 24 & 19 & 48 & 50 & 21 & 123 & 52 & 101 & 171 & 67 & 23 & 40 & 27 & 46 & 58 & 42 & 43 & 37 & 30 & 1022 \\
2009 & 27 & 21 & 50 & 52 & 25 & 134 & 58 & 106 & 188 & 72 & 25 & 41 & 27 & 45 & 66 & 46 & 49 & 38 & 35 & 1105 \\
2010 & 29 & 26 & 56 & 49 & 28 & 130 & 61 & 109 & 204 & 78 & 29 & 41 & 25 & 48 & 73 & 57 & 69 & 37 & 27 & 1176 \\
2011 & 19 & 27 & 45 & 32 & 12 & 90 & 36 & 73 & 124 & 65 & 0 & 42 & 18 & 42 & 36 & 51 & 72 & 26 & 24 & 834 \\
Total & 99 & 93 & 199 & 183 & 86 & 477 & 207 & 389 & 687 & 282 & 77 & 164 & 97 & 181 & 233 & 196 & 233 & 138 & 116 & 4137 \\
\hline
\end{tabular}

The financial data and the basic information on listed corporations in the model stem from GuoTaian's database of CSMAR in Chinese securities market, statistical software SPSS19.0 is used to conduct multiple regression. 


\section{The Empirical Results and Analysis}

According to the above analysis, I use the annual data in this paper and accruals are divided into discretionary accrual items and non-discretionary accruals to study the existence of conservatism of accounting earnings and its cause of formation after accounting standards for enterprises promulgated, the results of multiple regression are elaborated as follows:

\subsection{Descriptive Statistical Analysis}

Descriptive statistics of variables in Model 3, Model 4 and Model 5 are put into Table 2 about sample firms in 2008, concrete analysis is as follows: (1) ACC's mean value is -0.0109 , on the average, accruals of the sample firms are negative, maximum value and minimum value are respectively $1.3002,-0.3783$, which indicates that accruals of sample companies have the certain differences. (2) The mean value about OperAcc is 0.0821 , on the average, discretionary accrual about sample firms is positive, the maximum value and minimum value are respectively $1.2617,2.5056 \times 10^{-5}$, which shows that discretionary accrual items of samples are greatly different. (3) The mean value about NoperAcc is -0.09292 , on the average, non-discretionary accruals about sample firms is negative, the maximum value and minimum value are respectively $0.3223,-1.3462$, which suggests that non-discretionary accrual items of samples have certain difference. (4) The mean value about CFO is 0.0601 , on the average, the cash flow of operating activities about sample firms is positive, the maximum value and minimum value are respectively $0.6202,-0.7321$, which indicates that the cash flow of operating activities between different companies is different. (5) The mean value about DCFO is 0.2114 , the variable is virtual, which indicates that the net cash flow of operating activities in $21.14 \%$ of the sample firms is negative. The descriptive statistics of variables in 2009, 2010 and 2011 are the same with the above, thus no longer stated, but their descriptive statistics are listed in Table 3, Table 4 and Table 5.

Table 2. Descriptive statistics in Model 3, Model 4 and Model 5 in $2008(\mathrm{~N}=1022)$

\begin{tabular}{lllll}
\hline & Maximum Value & Minimum Value & Mean Value & Std.Deviation \\
\hline ACC & 1.3002 & -0.3783 & -0.0109 & 0.1180 \\
OperAcc & 1.2617 & $2.5056 \times 10^{-5}$ & 0.0821 & 0.0925 \\
NoperAcc & 0.3223 & -1.3462 & -0.0929 & 0.1350 \\
CFO & 0.6202 & -0.7321 & 0.0601 & 0.1120 \\
DCFO & 1 & 0 & 0.2114 & 0.4085 \\
\hline
\end{tabular}

Table 3. Descriptive statistics in Model 3, Model 4 and Model 5 in 2009 ( $\mathrm{N}=1105)$

\begin{tabular}{lllll}
\hline & Maximum Value & Minimum Value & Mean Value & Std.Deviation \\
\hline ACC & 0.6590 & -0.7152 & -0.0258 & 0.1086 \\
OperAcc & 0.6910 & $8.03216 \times 10^{-6}$ & 0.0729 & 0.0790 \\
NoperAcc & 0.0979 & -1.4062 & -0.0988 & 0.1375 \\
CFO & 1.0747 & -0.6310 & 0.0830 & 0.1176 \\
DCFO & 1 & 0 & 0.1520 & 0.3592 \\
\hline
\end{tabular}

Table 4. Descriptive statistics in Model 3, Model 4 and Model 5 in 2010 ( $\mathrm{N}=1176)$

\begin{tabular}{lllll}
\hline & Maximum Value & Minimum Value & Mean Value & Std.Deviation \\
\hline ACC & 0.7002 & -0.4555 & 0.0207 & 0.1108 \\
OperAcc & 0.6994 & $7.67922 \times 10^{-5}$ & 0.0786 & 0.0847 \\
NoperAcc & 0.1688 & -0.9056 & -0.0579 & 0.0833 \\
CFO & 0.6044 & -0.4693 & 0.0503 & 0.1117 \\
DCFO & 1 & 0 & 0.2372 & 0.4256 \\
\hline
\end{tabular}

Table 5. Descriptive statistics in Model 3, Model 4 and Model 5 in $2011(\mathrm{~N}=834)$

\begin{tabular}{lllll}
\hline & Maximum Value & Minimum Value & Mean Value & Std.Deviation \\
\hline ACC & 0.6051 & -0.4856 & 0.0165 & 0.1006 \\
OperAcc & 0.6277 & 0.0001 & 0.0796 & 0.0730 \\
NoperAcc & -0.0002 & -0.6222 & -0.0631 & 0.0809 \\
CFO & 0.7691 & -0.3994 & 0.0398 & 0.1095 \\
DCFO & 1 & 0 & 0.3058 & 0.4610 \\
\hline
\end{tabular}




\subsection{The Results of Multiple Regression and Analysis}

Model 3, Model 4 and Model 5 are respectively Ball and Shivakumar's (2005) original model of accrued-cash flow and its modified model, accruals in the modified model are divided into discretionary accrual items and non-discretionary accrual items. And the cross-sectional data used in various models has been elaborated in the front, namely annual regression, regression results about Model 3 are in Table 6, regression results about Model 4 are in Table 7, regression results about Model 5 are in Table 8. Now the analysis of regression results about different models are as follows: (1) In addition to the 2008 and the rest of the year, the regression results in Model 3 show that CFO and ACC is significantly negative, which indicates that accruals can reduce the "noise" of cash flow, but in addition to the 2008 the interactive items between CFO and DCFO is not significant, the interactive items in the rest of the year are significantly negative, the results contradict the coefficient of the interaction which is significantly positive in the original model of accrued-cash flow, namely Model 3 failed to verify the existence of accounting conservatism in China. (2) The regression results in Model 4 show the coefficient of CFO in each year are all positive, which is not compatible with the coefficient of CFO which is significantly negative in the original model of accrued-cash flow, in addition to the 2008, the interactive items between CFO and DCFO is not significant, in the remainder of the year the coefficient is significantly negative, the conclusion is contrary to the coefficient of the interactive items which is significantly positive in the original model of accrued-cash flow; Model 4 failed to examine the presence of accounting conservatism of listed corporations in China. (3) Regression results in Model 5 are described as follows: First, the coefficient of CFO each year is significantly negative at the $1 \%$ significance level, which just verifies accruals deduct the "noise" of cash flow in the accrued-cash flow model, and this is caused by non-discretionary accrual items in accruals; Secondly, in the period during from 2008 to 2011, the coefficients of CFO and DCFO interaction are significantly positive, which indicates the positive relativity between non-discretionary accrual items and negative operating cash flow is stronger, and this further explains losses can be reflected than gains in a timely manner, which indicates that accounting earnings in China is conservative, the conclusion is consistent with the significantly positive interaction coefficient in accrued-cash flow model. Finally, the fitting degree of the regression of the model is better, and there is no multicollinearity problems. From the results of regression analysis about the above 3 models from 2008 to 2011, conclusions can be drawn: accounting earnings is conservative in China, and accounting conservatism is determined by the non-discretionary accruals.

Table 6. The results of multiple regression on Model 3- total accruals ACC

\begin{tabular}{lllll}
\hline & 2008 & 2009 & 2010 & 2011 \\
\hline Cons & $-0.0107^{*}$ & $-8.4348 \times 10^{-5}$ & $0.0245^{* * *}$ & $0.0140^{* * *}$ \\
(T value) & $(-1.6867)$ & $(-0.0216)$ & $(6.9398)$ & $(3.3925)$ \\
CFO & -0.0094 & $-0.4527^{* * *}$ & $-0.4231^{* * *}$ & $-3992^{* * *}$ \\
(T value) & $(-0.1986)$ & $(-16.0253)$ & $(-14.4039)$ & $(-11.1819)$ \\
DCFO & 0.0140 & 0.0467 & 0.0238 & 0.0278 \\
(T value) & $(0.3304)$ & $(1.6193)$ & $(0.9380)$ & $(0.7808)$ \\
CFO $\times$ DCFO & 0.0109 & $-0.2630^{* * *}$ & $-0.4045^{* * *}$ & $-0.3444^{* * *}$ \\
(T value) & $(0.2428)$ & $(-9.0734)$ & $(-14.5812)$ & $(-9.4505)$ \\
$\mathrm{N}$ & 1022 & 1105 & 1176 & 834 \\
Adj-R ${ }^{2}$ & 0.0027 & 0.4385 & 0.6228 & 0.4867 \\
F value & 1.0840 & 288.3412 & 647.5693 & 264.2602 \\
Durbin-Watson & 1.8343 & 1.9141 & 1.8442 & 1.9573 \\
\hline
\end{tabular}

Notes: *,**,*** respectively represent the $10 \%, 5 \%, 1 \%$ level of significance.

Table 7. The results of multiple regression on Model 4-discretionary accruals OperAcc

\begin{tabular}{lllll}
\hline & 2008 & 2009 & 2010 & 2011 \\
\hline Cons & $0.0343^{* * *}$ & $0.0228^{* * *}$ & $0.0406^{* * *}$ & $0.0440^{* * *}$ \\
(T value) & $(8.8758)$ & $(8.0802)$ & $(14.5520)$ & $(14.0250)$ \\
CFO & $0.4728^{* * *}$ & $0.5642^{* * *}$ & $0.2117^{* * *}$ & $0.2653^{* * *}$ \\
(T value) & $(12.9746)$ & $(20.0609)$ & $(6.9749)$ & $(7.0927)$ \\
DCFO & 0.0015 & $0.1628^{* * *}$ & $0.0892^{* * *}$ & $0.0896^{* *}$ \\
(T value) & $(0.0461)$ & $(5.6633)$ & $(3.4023)$ & $(2.3996)$ \\
CFO $\times$ DCFO & -0.8597 & $-0.7018^{* * *}$ & $-0.8636^{* * *}$ & $-0.7527^{* * *}$ \\
T value) & $(-24.7449)$ & $(-24.3162)$ & $(-30.1398)$ & $(-19.7111)$ \\
$\mathrm{N}$ & 1022 & 1105 & 1176 & 834 \\
Adj-R & 0.4006 & 0.4434 & 0.5974 & 0.4363 \\
F value & 228.4422 & 294.2019 & 582.2903 & 215.9140 \\
Durbin-Watson & 2.0117 & 1.8829 & 1.9032 & 1.9775 \\
\hline
\end{tabular}

Notes: $*, * *, * * *$ respectively represent the $10 \%, 5 \%, 1 \%$ level of significance. 
Table 8. The results of multiple regression on Model 5-non-discretionary accruals NoperAcc

\begin{tabular}{lllll}
\hline & 2008 & 2009 & 2010 & 2011 \\
\hline Cons & $-0.0538^{* * *}$ & $-0.0229^{* * *}$ & $-0.0161^{* * *}$ & $-0.0300^{* * *}$ \\
(T value) & $(-8.2016)$ & $(-4.2580)$ & $(-4.4163)$ & $(-7.9114)$ \\
CFO & $-0.4955^{* * *}$ & $-0.6817^{* * *}$ & $-0.7780^{* * *}$ & $-0.7357^{* * *}$ \\
(T value) & $(-11.6709)$ & $(-22.1497)$ & $(-19.3304)$ & $(-18.0417)$ \\
DCFO & 0.0335 & $-0.0566^{*}$ & $-0.0590^{*}$ & -0.0462 \\
(T value) & $(0.8807)$ & $(-1.7995)$ & $(-1.6972)$ & $(-1.1355)$ \\
CFO $\times$ DCFO & $0.1342^{* * *}$ & $0.1955^{* * *}$ & $0.3399^{* * *}$ & $0.2507^{* * *}$ \\
(T value) & $(3.3144)$ & $(6.1889)$ & $(8.9452)$ & $(6.0211)$ \\
$\mathrm{N}$ & 1022 & 1105 & 1176 & 834 \\
Adj-R & 0.1864 & 0.3334 & 0.2919 & 0.3301 \\
F value & 78.9706 & 185.0149 & 162.4235 & 137.8540 \\
Durbin-Watson & 1.9791 & 1.9023 & 1.9679 & 2.0215 \\
\hline
\end{tabular}

Notes: ${ }^{*},{ }^{* *},{ }^{* * *}$ respectively represent the $10 \%, 5 \%, 1 \%$ level of significance.

\section{Sensitivity Test}

I will conduct the sensitivity test for the model in order to make the research results more reliable. The empirical study part of the front, the cross-sectional data of the selected samples are used in solving discretionary accruals and non-discretionary accrual items, and the calculation of non-discretionary accruals and discretionary accruals is obtained by the basic Jones' model to solve industry characteristic parameters first, and then the characteristics parameters of industry are substituted in the modified Jones' model. In using Jones' model in both China and other countries, many people select panel data, discretionary accrual and non-discretionary accrual items are directly solved through modified Jones' model. For example, Su and Lin (2010) used the modified Jones' model to solve discretionary accrual items, and applied panel data. Therefore, the specific approach is in the test of the sensitivity as follows: (1) selecting panel data, namely data of 4 years from 2008 to 2011 as a whole body; (2) directly using the modified Jones' model to obtain the accruals, discretionary accrual and non-discretionary accrual items. This requires the establishment of the modified Jones' model, as Model 6 (variables defined in the model are uniform with the front). Combining Model 6 with Model 2, we can get accruals, discretionary accrual items and non-discretionary accrual items. Then the results are substituted into Model 3, Model 4 and Model 5 to test, the results of regression are put in Table 9.

$$
\frac{G T A_{i, t}}{A_{i, t-1}}=a_{1} \frac{1}{A_{i, t-1}}+\alpha_{2} \frac{\Delta R E V_{i, t}-\Delta R E C_{i, t}}{A_{i, t-1}}+\alpha_{3} \frac{P P E_{i, t}}{A_{i, t-1}}+\varepsilon_{i, t}
$$

(Model 6)

Table 9. The results of sensitivity test on Model 3, Model 4 and Model 5 ( $\mathrm{N}=4137)$

\begin{tabular}{llll}
\hline & Model 3 & Model 4 & Model 5 \\
\hline Cons & $0.0058^{* *}$ & $0.0339^{* * *}$ & $-0.0282^{* * *}$ \\
(T value) & $(2.8345)$ & $(21.3263)$ & $(-11.0604)$ \\
CFO & $-0.3787^{* * *}$ & $0.4078^{* * *}$ & $-0.6642^{* * *}$ \\
(T value) & $(-24.2511)$ & $(24.7610)$ & $(-34.7911)$ \\
DCFO & $0.0308^{* *}$ & $0.0922^{* * *}$ & $-0.0367^{* *}$ \\
(T value) & $(2.0832)$ & $(5.9102)$ & $(-2.0310)$ \\
CFO $\times$ DCFO & $-0.3846^{* * *}$ & $-0.8286^{* * *}$ & $0.2251^{* * *}$ \\
(T value) & $(-25.0210)$ & $(-51.1072)$ & $(11.9788)$ \\
Adj-R ${ }^{2}$ & 0.5142 & 0.4600 & 0.2739 \\
F value & 1460.1907 & 1173.3010 & 521.0664 \\
Durbin-Watson & 1.8977 & 1.9411 & 1.9265 \\
\hline
\end{tabular}

Notes: $* * *, * * *$ respectively represent the $10 \%, 5 \%, 1 \%$ level of significance.

According to Table 9, the regression results on Model 3 show that the coefficient of CFO is significantly negative, which is the same with Ball and Shivakumar's (2005) original model of accrued-cash flow, but the coefficient of interaction on CFO and DCFO is significantly negative, which is apparently contrary to the original model of accrued-cash flow. The regression results on Model 4 show that the coefficient of CFO is significantly positive, which contradicts the original model of accrued-cash flow, and the coefficient of 
interaction on CFO and DCFO is significantly negative, and the result is also not consistent with Ball and Shivakumar's (2005) original model. The regression results on Model 5 are described as follows: (1) the coefficient of CFO in the model is significantly negative, which has verified the accruals (exactly non -discretionary accrual items) offset the "noise" of operating cash flow so that the original model of accrued-cash flow is correct; (2) the coefficient of interaction of CFO and DCFO is significantly positive, which indicates the positive correlation between non-discretionary accrual items and negative cash flow is stronger, and this also verified negative cash flow are timely reflected by non-discretionary accrual items, or the loss can be more timely reflected than income, namely accounting earnings has conservatism. In the sensitivity test, the regression results of using panel data in Model 3, Model 4 and Model 5 are consistent with the cross-section data above. This further validates accounting earnings is conservative in capital market of China, and the conservatism stems from non-discretionary accrual items.

\section{Research Conclusion and Prospect}

I adopt the listed corporations of A-shares in Shanghai and Shenzhen of China from 2008 to 2011 as research samples in this paper, the purpose is to test if the conservatism of accounting earnings does exist in Chinese listed corporations after the implementation of the new accounting standards for enterprises? And exploring its origins. First, individually tested according to annual namely cross-sectional data, I have used the panel data to inspect in the sensitivity test in order to make the results more reliable. In choosing the model, using Ball and Shivakumar's (2005) accrued-cash flow model, but the original model has been modified, namely accruals are divided into discretionary accrual items and non-discretionary accrual items. So 3 models have been built, the 3 models have been respectively conducted multiple regression in order to clarify the existence of the conservatism and its root of formation. The conclusion is that China's accounting earnings are conservative, but its cause of formation is non-discretionary accrual items. Obviously this conclusion is not entirely consistent with the accounting conservatism steming from accruals in Ball and Shivakumar's (2005) accrued-cash flow model, the reason may lie in the existence of difference in the capital market of China and other countries or accounting method of two kinds of capital market themselves. Therefore, in using China's capital market as samples and using the original model of accrued-cash flow to test, the conclusion is different from the original model, so accruals should be further explored, namely it is divided into discretionary accrual items and non -discretionary accrual items. After having been handled, I find accounting earnings is conservative in the capital market of China, but its cause stems from non-discretionary accrual items. The reason of this conclusion is accrual (non -discretionary accrual items) can confirm timely the economic profit and loss, but which is mainly due to the forecast for the future, and non-discretionary accruals is mainly the prediction of future profit and loss of the companies. Therefore, the role that the economic profit and loss are timely confirmed can be reflected by non -discretionary accrual items.

The econometric model of the empirical research of accounting conservatism, in addition to Ball and Shivakumar's (2005) accrued-cash flow model, includes Basu's earnings-stock return model etc. So other models will be considered to study the accounting conservatism in the future. Of course, listed corporations should be also chosen to act as the object of study in the foreign capital market, or listed corporations of B-share will be researched in the capital market of China. In addition, listed corporations for ST and PT can be also considered to conduct empirical study.

\section{Acknowledgements}

This paper is the stage research achievements on the topic which is the Research on Fair Value Measurement and Accounting Conservatism-the Comparison and Discussion before and after new Accounting Standards for Enterprises Reformed in China. And this topic derives from China Commercial Accounting Institute. Serial Number of the Topic: kj201230

\section{References}

Ahmed, A. S., Billings, B. K., Morton, R. M., \& Stanford, M. H. (2002). The role of accounting conservatism in mitigating. Bondholder-sharebolder conflicts over dividend policy and in reducing debt costs. The Accounting Review, 77(4), 867-890. http://dx.doi.org/10.2308/accr.2002.77.4.867

Ball, R., \& Shivakumar, L. (2005). Earnings quality in U.K. private firms. Journal of Accounting and Economics, 39, 83-128. http://dx.doi.org/10.1016/j.jacceco.2004.04.001

Basu, S. (1997). The conservatism principle and the asymmetric timeliness of earnings. Journal of Accounting and Economics, 24, 3-38. http://dx.doi.org/10.1016/S0165-4101(97)00014-1

Bliss, J. H. (1924). Management through accounts. New York, NY: The Ronald Press Co. 
Francis, J. R., Maydew, E. L., \& Sparks, H. C. (1999). The role of big 6 auditors in the credible reporting of accruals. Auditing: A Journal of Practice and Theory, 18, 17-34. http://dx.doi.org/10.2308/aud.1999.18.2.17

Givoly, D., \& Hayn, C. (2000). The changing time-series properties of earnings, cash flows and accruals: Has financial accounting become more conservative? Journal of Accounting \& Economics, 29, 287-320. http://dx.doi.org/10.1016/S0165-4101(00)00024-0

Healy, P. M. (1985). The Effect of Bonus Schemes on Accounting Decisions. Journal of Accounting and Economics, 7, 85-107. http://dx.doi.org/10.1016/0165-4101(85)90029-1

Holthausen, R. W., \& Watts, R. L. (2001). The Relevance of the Value-Relevance Literature for Financial Accounting Standard Setting. Journal of Accounting \& Economics, 31, 700-775. http://dx.doi.org/10.1016/S0165-4101(01)00029-5

Hong, J., \& Xu, Y. (2009). Empirical Evidence about the Governance Effect of the Second Major Shareholder in Listed Corporations-Based on the perspective of Accounting Conservatism. Finance Research, 8, 55-58.

Kothari, S. P., Lys, T., Smith, C. W., \& Watts, R. L. (1988). Auditor liability and information disclosure. Journal of Accounting, Auditing and Finance, 3, 307-339.

Lara, J. M. G., Osma, B. G., \& Araceli, M. (2005). The effect of earnings management on the asymmetric timeliness of earnings. Journal of Business Finance \& Accounting, 32(4), 696-726.

Li, Z., \& Lu, W. (2003). The Conservatism of Accounting Earnings: Discovery and Enlightenment. Accounting Research, 2, 19-27.

Liu, D. (2011). Effectiveness Inspection of Accruals' Models- Based on the Empirical Study in Chinese Capital Market. Journal of ZhongNan University of Economics and Law, 1, 85-91.

Qiu, Y., \& Qu, X. (2009). Discretionary Accruals and Earnings Conservatism: Evidence from China's Stock Market. Contemporary Finance \& Economics, 9, 105-109.

Su, D., \& Lin, D. (2010). CEO Stock Incentives, Earnings Managementand Corporate Governance. Economic Research, 11, 88-100.

Subramanyam, K. R., \& Wild, J. J. (1996). Going-Concem Status, Eamings Persistence, and Informativeness of Eamings. Contemporary Accounting Research, 13(1), 251-273. http://dx.doi.org/10.1111/j.1911-3846.1996.tb00500.x

Watts, R. L. (1993). A proposal for research on conservatism. Unpublished working paper, University of Rochester, Presented at the AAA meetings, San Francisco, CA.

Xia, D., \& Zhu, S. (2009). A Study of Accounting Conservatism: Based on the Relation between Accruals and Cash Flow. Contemporary Finance \& Economics, 5, 98-102.

Xia, L. (2003). Application of Earnings Management Measuring Models in the Chinese Stock Market. China Accounting and Finance Review, 6, 94-154.

Zhao, C. (2004). The Accounting Reform and Conservatism Improved in China. The World Economy, 4, 53-62.

\section{Notes}

Note 1. On operating profit for boundaries, the items above operational profit are called online items, they are considered regular projects; the items below operational profit are called the items below the line, they are considered mostly accidental. The total accruals before the items below the line is equal to operating profit plus net cash flow of operating activities; the total accruals including the items below the line is equal to net profit plus net cash flow of operating activities.

Note 2. The new accounting standards for enterprises issued in February 15, 2006 stipulates that the amount of fixed assets in balance sheet is only disclosed net amount, so based on access to data, the value of fixed assets in Jones' model and modified Jones' model model is taken net value.

Note 3. Xia Lijun's (2003) results through empirical research have showed that earnings management can be more effectively revealled by the total accruals before the items below the line, so here I use operating profit rather than net profit in the calculation of total accruals. 